\title{
Menstrual Blood as a Weapon of Resistance
}

THERESA O'KEEFE

University College Dublin, Ireland

\begin{abstract}
This paper examines how women in the North of Ireland used menstrual blood as a means of resisting the state. It explores the central role that menstrual blood and menstruation have played throughout the conflict - both as an instrument of war and as a weapon of resistance for female political prisoners. Various arms of the state used menstruation as a means of control over republican women. But women also used menstrual blood to challenge and to resist such attempts by the state. This article suggests that the use of menstrual blood in resisting the state is an act so subversive that it effectively disrupted staunchly entrenched gender norms in Northern Irish society prior to the height of the conflict. This in turn provoked the rise of a distinct form of feminism rooted within the republican movement.
\end{abstract}

feminism, Ireland, menstruation, political prisoner, republican, resistance, war

\section{INTRODUCTION ${ }^{1}$}

The struggle to unite the six counties of the North of Ireland ${ }^{2}$ with the 26 county Republic provides clear illustrations of how women's bodies are targeted during conflict. ${ }^{3}$ In attempts to maintain its hold over the North of Ireland, the British state, through its various enforcement arms, has utilized gendered violence. At the hands of soldiers, prison guards and police officers, women have experienced strip-searches, rape, sexual assault, fondling and a litany of abuses. This article, in particular, focuses on how menstruation serves as a contested site of power. As this essay shows, hegemonic masculinity relies on menstruation; women's ability to menstruate is used as a justification for the creation and continuation of the public/private divide 
(De Troyer, Herbert and Johnson 2003). It is used, for example, to relegate women's place in the nation to that primarily of mother and in the general construction of the gendered nation. Furthermore, the gendered violence used to enforce hegemonic masculinity is intimately connected with women's menstruation. In the Northern Irish conflict, British state forces used menstruation as an instrument of war against republican women.

More significantly, menstruation became a weapon of resistance when women political prisoners reclaimed the ability to menstruate and used it against their captors. This had repercussions that extended outside the walls of Armagh jail and into Northern Irish society more widely, as it disrupted existing gender norms and relations by helping to spark the rise of a vigorous feminist movement within the nationalist community. ${ }^{4}$ The power in menstruation lies in its taboo - a taboo that exists among the oppressors (the British state) and oppressed (the republican community). Detailing how republican women subversively reclaimed menstruation emphasizes the connection between gendered violence and menstruation, as well as the importance of menstruation in attempts to discipline and control women's bodies. In addition, examining women's agency furthers our understanding of Britain's modes of domination.

While this paper will detail the implications of the use of menstruation as a political tool in the North of Ireland, such analysis has significance outside the confines of this case. The use of menstruation, as both a hegemonic and counter-hegemonic tool, is grossly understudied. Despite developing a huge field of inquiry around the gendered body, feminist literature has not adequately addressed the politicization of menstruation. In fact, we know little about how women's ability to menstruate is directly used against them, and in turn, how women have directly used menstruation in a subversive fashion to disrupt gender norms. As this paper will discuss (albeit briefly), menstruation is highly policed by societal norms in most cultures and communities. To understand how menstruation is used as a means to control women is to also appreciate the potential significance of menstruation as a resistance tool. Challenging the constructed taboo around menstruation can be a powerful resource for women interested in disrupting gendered societal norms, as the case of republican feminist resistance shows.

This article is part of a larger research project that investigates the rise and significance of feminist nationalism in the North of Ireland. It is based on a number of sources, including face-to-face semi-structured interviews conducted on the island of Ireland in 2000 with women who were involved in both the unarmed and armed elements of the republican movement. In addition, pamphlets, leaflets, political tracts, magazines, political memorabilia, collections of newspaper articles and other material related to the conflict provided valuable insight. Policy documents of parties like Sinn Féin and the Northern Ireland Women's Coalition were also used extensively in the analysis, as were documentaries made by women about their participation in the armed conflict. 
Foucault's view of power through discipline and punishment has served as an attractive theoretical tool for feminist analyses. Scholars such as Bartky (1995), Morgan (1991), Weitz (2001) and others have used Foucault to understand how women's bodies are constructed, controlled and manipulated in an attempt to reinforce rigid gender norms in relation to masculinity and femininity. As Bartky explains, for women, 'discipline produces subjected and practiced bodies, “docile” bodies' (1995: 240). Disciplinary practices regulate women's bodies in a manner "which is perpetual and exhaustive - a regulation of the body's size and contours, its appetite, posture, gestures, and general comportment in space and the appearance of each of its visible [and invisible] parts' (Bartky 1995: 254). In more specific terms (Morgan 1991: 36):

... a woman's makeup, dress, gestures, degree of cleanliness, odours, degree of hirsuteness, vocabulary, hands, feet, skin, hair, and vulva can all be evaluated, regulated, disciplined in the light of the hypothetical often-white male viewer and the male viewer present in the assessing gaze of other women.

Simply put, the behaviours, desires, pleasures and appearances of female bodies are a product of power relations (Grosz 1995: 32).

One important yet understudied means of disciplining women's bodies relates to menstruation. Menstruation and menstrual blood are long-standing, cross-cultural taboos. Masculinist disciplinary practices regulate all things menstrual to the private realm. Such 'menstrual etiquette' ensures a sense of fear, embarrassment and shame for women when it comes to menstruation (Laws 1990). Menstruation is a matter that a woman is expected to keep to herself. Any indicators that a woman is menstruating are meant to be hidden, invisible. Tampons and 'sanitary' pads are designed to be undetectable. Commercials that advertise such products avoid any reference to words like menstruation, blood or period and opt to illustrate the effectiveness of their product with blue liquid instead of red (Houppert 1999). In fact, advertisements of 'sanitary protection' have only appeared on British television (which includes television in the North of Ireland) since 1979, when experimental advertisements of such products were first run. It was not until 1988, however, that the Independent Broadcasting Authority in Britain permitted commercials for sanitary pads, tampons, belts, etc, to air on certain television networks. Furthermore, strict guidelines dictated such advertisements, prohibiting 'uncomfortable' or 'indiscrete' references to menstruation, hence the blue liquid used in ads to this day (Laws 1990: 46). Even in an era when sex and sexuality are not the taboo topics they once were, menstruation remains closeted.

Throughout history menstruation has been used as an excuse to devise separate spheres for women and men, thereby prohibiting women from many activities (De Troyer, Herbert and Johnson 2003). Ultimately, menstruation 
has been viewed as dirty, vile, impure, pollution (Douglas 1966; 0'Brien 1981; Laws 1990 : 32). The association of menstruation, menstrual blood, and therefore women, with dirt is not unlike attitudes dominant groups hold toward less powerful groups. As Laws suggests, the label 'dirty' has been used in the West as a means to subjugate the lower and under-class and various minority ethnic groups in an attempt to dehumanize them (Laws 1990: 36). ${ }^{5}$ In particular, women are assumed to be a priori dirty and, as a result, must strive to be clean, pure and wholesome, not only in behaviour but in appearance as well.

It is not surprising, therefore, that cleanliness and the act of cleaning have throughout history been associated with women. Whether through the division of labour in the home or the workplace, the responsibility for ensuring clean surroundings has customarily rested in the hands of women (Leddy 1995: 261). Gendered conceptions of cleanliness also extend into both the workplace and leisure activities. While women must endeavour to remain dirt-free, men, on the other hand, are associated, to a certain extent, with dirt through their socially acceptable relationship with lack of cleanliness in their often-'dirty' jobs like fixing cars and digging ditches. From the time they are boys, males are given the freedom to indulge in soiling their clothes and hands while playing, while girls are often denied that pleasure and relegated to much 'neater' activities such as 'playing house'. Hence, when a woman chooses to disregard gendered expectations of cleanliness, it is interpreted as a failure of being feminine whereas men in 'dirty' jobs do not need to fear an association of being 'less' masculine. Such gendered expectations regarding cleanliness further solidify the taboo of menstrual blood.

\section{MENSTRUATION AS AN INSTRUMENT OF WAR}

As Cockburn points out, during conflict "the instruments with which the body is abused in order to break the spirit tend to be gender differentiated and, in the case of women, to be sexualized' (Cockburn 2001: 22). Menstruation is quite effective as an instrument of war. The disciplinary practices that have relegated menstruation to the private realm have allowed it to become an area of vulnerability for women in a powerless position. ${ }^{6}$ In Northern Irish society, both Catholicism and a conservative form of Protestantism have served to entrench the ideal image of a woman as chaste, pure and desexualized, thus making more salient the sexualization and commodification of women's bodies (Inglis 1987; McWilliams 1993). Sex, bodies and female bodily functions are seen as shameful, embarrassing and therefore to be hidden. This is particularly germane for all things relating to menstruation. As former political prisoner Brenda Murphy explains (Murphy 1989: 226):

In Ireland you don't speak about your period. You don't even mention the word. My mother hardly ever mentioned it to us and we were a family of eight girls and one boy. You get your period, but you just don't talk about it. It's taboo. 
At best, menstruation is talked about among female friends, but periods are not something to be discussed with men. ${ }^{7}$ It is for such reasons that menstrual blood acts as a powerful instrument to be used against republican women as enemies of the state. This is most evident in republican women's encounters with British state forces throughout the history of the conflict in the North.

In the North of Ireland the Crown forces, including the Royal Ulster Constabulary (now the Police Service of Northern Ireland), the Ulster Defence Regiment, British soldiers, paratroopers, Special Branch agents and even prison authorities represent the coercive side of the British state. These crown forces were responsible for raids on the homes of the nationalist community, raids that were often intrusive and abusive. These 'security forces' interrogated republicans not only in their homes but also on the streets and inside police stations, detention centres and prison walls. Quite often these encounters were gendered. ${ }^{8}$ The nature of the abuse that republican women suffered at the hands of crown forces was usually linked to the female body. Republican women posed a threat to the prevailing order, as they were challenging the British presence on the island of Ireland and in doing so were transgressing gender norms by stepping out of the home and onto the streets (ThaparBjörkert and Ryan 2002; O'Keefe 2003b).

As a result of the place assigned for women in the nation - primarily as its embodiment and reproducers, women's bodies are a site of struggle for control (Copelon 1998; Nikolic-Risanovic 1998; Turshen 2001). Women, therefore, are to be protected during war and it is the role of 'their men' to protect them. It is deemed a victory for the enemy, then, if women are successfully besieged and the men are emasculated. In the Northern Irish case, the British repeatedly singled out republican women (Pickering 2001; Harris and Healy 2001). In particular, state forces targeted female bodies in a sexual manner as a means of intimidation and humiliation in the hopes of breaking the republican movement. Hatred and bigotry in the North toward republicans, and Catholics more generally, also fuelled this gendered treatment. The Royal Ulster Constabulary (RUC), precursor to the Police Service of Northern Ireland (PSNI), was a predominantly Protestant force that was continually accused of collusion with loyalist paramilitaries, which, in turn, gave rise to a form of institutionalized bigotry (McGarry and 0'Leary 1995: 124). ${ }^{9}$ The gendering of abuse offered many options for crown forces. Male detainees were physically abused; they were often kicked, beaten, left badly bruised and with broken bones. They experienced emotional and verbal assault. In addition to such forms of abuse, women experienced sexual harassment and assault in various locations in the home and on the streets. Crown forces would stop at nothing to cause degradation and distress, and one of the more effective means of doing this was to target women's ability to menstruate. The focus on menstruation effectively capitalized on conservative attitudes in Northern Irish society on such matters. 
The British state used raids as one of the more intrusive measures to curb the republican movement. They were often as much about harassment as they were 'fact-finding missions'. As one woman recalls:

Everything, all your personal belongings have been interfered with. There was one time, my house was searched, and my parents were not very well, and the house was searched. And one of the British soldiers actually urinated all over the carpet on the stairs in front of us ... And for months after it, we felt that our home wasn't our home. That it had been violated in such a terrible way.

(Harris and Healy 2001: 20)

These raids left an indelible mark on the memory of those who suffered from them. Many republican women have provided accounts of how British soldiers rifled through every personal and intimate belonging in the household (Fairweather, McDonough and McFaydean 1984: 16). The items unearthed and brought into 'plain view' included women's underwear and sanitary products. Women report how soldiers took the opportunity to sexualize these raids, holding out women's panties and asking them, 'Who were you wearing this for? What bastard were you wearing this for last night?' (Harris and Healy 2001: 54). Menstrual products were also targets and among the most humiliating of personal items to be disclosed. As one women recalls: 'And all your personal bits from tampax to sanitary towels had been pulled out of drawers and thrown all over the place' (Harris and Healy 2001: 20). It was this act that was perceived as the gross and unwarranted violation of privacy.

Patrols of republican communities by the British Army offered another avenue for harassment. Women recall how patrols searched them in the middle of the street. Though a female officer conducted these searches for the most part, male soldiers watched, jeered and made sexual remarks (Harris and Healy 2001: 76). These army patrols were also guilty of using menstrual blood as a means of degrading republican women. One woman reported an incident where British soldiers, after standing outside her home shouting repeatedly 'Come out, you whore', left a statue of the Virgin Mary in her garden, defaced with red paint on the crotch (Fairweather, McDonough, and McFaydean 1984: 19). This act of sacrilege against the Virgin Mary statue not only railed against Catholicism and its most important female icon, but it also served as an attempt to disrupt any association of women with purity and as a reminder that as long as women menstruate they can never be pure or clean.

Another common experience among members of the republican community was interrogation by state forces. This interrogation ranged from simple requests for names and addresses, to abusive language, severe beatings and even torture if detained or arrested. Many stories recount the abuse republican men and women in Castlereagh (RUC and Special Branch headquarters in Belfast) suffered at the hands of the predominantly Protestant police and British Army (Faul and Murray 1972; Murray 1998; 'Sexual Harassment: British Occupation' n.d.: 12). For women, sexual harassment of some sort 
frequently accompanied interrogation, whether on the street, at barracks, or in police stations. At the very least, state forces used sexual slurs as a means of intimidation during interrogation. Horror stories have surfaced over the past two decades concerning the abuse women suffered in the North at the hands of British soldiers and police (e.g. 'Sexual Harassment: British Occupation' n.d.: 12). Accounts of young girls being pulled off the streets at gunpoint and being forced to insert their own fingers into their vaginas are some of the more jarring that have emerged over the years of the conflict. The situation was worsened by the fact that soldiers or officers of the crown were rarely reprimanded for their actions. ${ }^{10}$ This legitimization of rape and sexual assault by the British state placed women in a precarious position and made their experiences in this conflict zone different from their republican male counterparts'. Techniques used by crown forces when interrogating women include verbal abuse, such as insulting women about their appearance and weight. Furthermore, women were "called a variety of names such as "whore" and "slut" and... threatened with being raped in the interrogation room or cell' (McArdle and Carrol 1992: 6). Sexual abuse that women faced in these situations included:

... obscenities being shouted or whispered into the woman's ear, attempts to kiss her, rub her thighs, touch her breasts or rub up against her ... [The interrogators in such situations were] using a woman's sexuality as a weapon against her.

(McArdle and Carrol 1992: 6)

Women of all ages and stages in their lives, including those who were pregnant, ill, or quite young, suffered such forms of intimidation and abuse.

Importantly, state forces utilized menstruation in such instances to punish republican women. For example, interrogators (regardless of their gender) denied women personal hygiene or the use of sanitation facilities. The following is an account of a 1978 interrogation of a 13-year-old girl, presented in her own words.

The RUC and the British Army came to my home. They nearly put the door in and when my Daddy opened the door they said they were there to raid the house. My Daddy said 'not again', as they came on Tuesday. They asked who was in the house, Daddy went up the stairs and one ran in front of him, the other one pushed my Daddy out of the way, and came into my bedroom and pulled me out of the bed. I was very frightened and started to cry. They pulled me down the stairs.

I took my periods at this stage and I told the policewoman as it was running down my legs. She said 'Let it $\mathrm{f}$... run down your legs, you are not going to get a sanitary towel' ... They were pulling me out into the Saracen [armoured personnel carrier]. They twisted my arm up my back, and when they threw me into the Saracen they bumped my head ... They tore my coat as they were pulling me ...

(McCafferty 1981: 33) 
Other women have reported similar stories. Republican women shared the fear of starting their periods while under interrogation. Even something as simple as asking for sanitary protection turned into a humiliating experience. When, for example, Brenda Murphy had to inform her male interrogator at the time of her arrest that her period had arrived and she was therefore in need of sanitary towels, he responded with disgust. The police officer replied, 'Have you no shame? I've been married twenty years and my wife wouldn't mention things like that' (Murphy 1989: 226). Those women who were afforded the luxury of some form of sanitary protection were then forced to deal with applying the pad and washing themselves with no privacy. The door to the bathroom remained open at all times and under a police officer's supervision, therefore requiring women to insert or attach their sanitary protection in full view. Many republican women often relinquished their access to sanitary towels, pads or tampons to avoid changing in public (Harris and Healy 2001: 60). One woman explains the permeating and prevalent fear:

They have a chain on the door of the bathroom an' then your cell's on the corridor. You go into the bathroom an' you can put the chain on the door but it's open. So I just washed in the sink and all I ever washed was my hands and face. And I didn't give a fuck if I was stinking it was [not?] my fault but then when I was down in the cell I thought 'If my period starts, I'm fucked'.

(Harris and Healy 2001: 34)

Gendered violence did not stop after republicans left the interrogation site. Once in prison women were continually subjected to the same forms of harassment they received while in questioning. The British state institutionalized abuse through the prison system to conduct human rights violations ostensibly free from view of the world, free from the lens of a camera (Amnesty International 1978). Prisoners experienced a level of punishment far beyond that allotted in a courtroom on the day of sentencing. Among the more brutal forms of punishment directed at political prisoners was strip-searching. This practice was a harsh means of control exercised over both men and women at the hands of the prison authorities acting on behalf of the British government. Men and women in republican jails throughout England and Ireland experienced this gruesome ordeal repeatedly. For the female prisoners, however, the sexual climate in which many of the searches took place often made strip searches a form of sexual assault and abuse instead of a purely physical means of intimidation.

The majority of the women who faced strip-searching on a recurring basis were those on remand who had to leave the prison many times a week for a court appearance. These women were searched when leaving and entering the prison, despite the fact that they were accompanied by a police officer or prison official at all times (Women's News 1984: 7). Those conducting the strip searches did not discriminate on the basis of age or circumstance, as both young and old were forced through the process, as were women 
who were pregnant or had just given birth. If a woman refused to strip, as many did in defiance of this practice, security forces forcibly removed her clothes, even in the presence or with the help of male officers (Maghaberry Republican Prisoner's Statement 1987: 17). Moreover, the environment in which these searches were conducted was a hostile one, as those carrying out the procedure often regarded the republican women with contempt. A former prisoner recounts her personal knowledge of strip-searching:

You are alone in an atmosphere of hostility, you are stripped not only of your clothing but every attempt is made to strip you of your self-respect. Your body is scrutinised inch by inch, hands are run along the sides of your feet and the back and palms of your hands, around your neck and through your hair, every action meticulously and slowly performed.

('Strip Searching ... Violence Against Women’ 1986: 6)

Strip-searching continued until the last female political prisoner was released from Maghaberry under the terms of the Good Friday Agreement of 1998. Furthermore, though prison security was used to justify strip searches, statistics indicate that all the strip searches conducted throughout English or Irish jails resulted in the confiscation of very few items. Statistics released by the Northern Ireland Office suggest that when strip-searching was at its height in the early to mid 1980s in Armagh, it was of little value in terms of finding prohibited goods. During this period, when an estimated 2,000 strip searches were carried out, no prohibited articles were found (Loughran 1985). Such statistics confirm what many women suspected - that:

... degradation, control and submission rather than security were on the agenda ... The Northern Ireland Office [NIO] want to terrorise women prisoners, to beat us into submission because we continue to defy their attempts to impose their will on us.

(Women's News 1991: 5)

Indeed, readily available metal detectors could have been used if security was in reality of the utmost concern.

Despite the fact that strip-searching was itself a malicious instrument of war that punished and degraded republican women, it was made far worse by menstruation (Aretxaga 2001). A menstruating woman was 'forced to remove her sanitary protection and hand it over for inspection. She remains totally naked and "unprotected" until the visual body inspection and search of her clothing is completed; only then is her sanitary protection returned' (Maghaberry Republican Prisoner's Statement 1987: 17). Speaking of their experiences with menstruation while strip-searched, female prisoners proclaimed, 'There is no degree of decency preserved throughout a strip search. It is simply a debasing and revolting practice' ('Strip-Searching... Violence Against Women' 1986: 6). Prison authorities were well aware of the negative 
impact this practice had not only on the bodies of the women being searched but on their psyches as well. The stress that accompanied the anticipation of a strip search had a profound effect on the women. Many lost weight and stopped menstruating because of the fear of being on their periods at the time ('Testimony of Mairéad Farrell' 1987). As Irish journalist Nell McCafferty proclaimed, 'It has come to this then. The war in Northern Ireland, reduced within the confines of a woman's prison to searching through a blood soaked sanitary towel for smuggled tobacco' (McCafferty 1981: 10). Similar searches were also conducted on women visiting political prisoners in jail in the North. Women were forced to lift their skirts and take down their tights. If a woman was menstruating she had to remove the sanitary towel for inspection (Fairweather, McDonough and McFaydean 1984: 63). ${ }^{11}$ This was a humiliating experience for women, particularly since many of the women visiting prisoners were mothers and thus were older and of an even more reserved generation regarding issues like women's bodies and menstruation (Murphy 1989: 286).

To make women remove their sanitary pads when visiting political prisoners served as another method to humiliate and to punish the republican community. As much as women's bodies offered an enticing target of state-sponsored sectarianism and punishment, women's ability to menstruate in fact heightened the value of such punishment. Whether in raids, interrogations, arrests, or strip searches, menstruation has been used as a tool to enervate republican women. However, as state forces found out, menstrual blood was not only an instrument of war, a target for control. Republican women themselves could also manipulate menstrual blood to their own advantage.

\section{MENSTRUAL BLOOD AS A WEAPON OF RESISTANCE}

The Dirty Protest is one of the more trying times in the history of the republican armed struggle. This was a difficult time for all prisoners taking part in the strike and for the families who had relatives in prison at the time. For male prisoners, the Dirty Protest came into being several months after the start of the 'blanket protest'. In September 1976, republican prisoner Ciaran Nugent was the first prisoner to be criminalized, meaning the explicit denial of a category of political status and the 'benefits' associated with it. Rejection of political status meant that republican (and loyalist) prisoners had to wear prison uniforms, perform prison work and, most importantly, were not seen as prisoners who were incarcerated because of their political actions and beliefs. In protest of his criminalization, Nugent refused to wear the prison clothes provided him and perform the duties allotted to him. For the duration of his prison sentence he wore only a blanket and was joined by new inmates on this blanket protest. Those prisoners 'on the blanket' were denied access to reading and recreational materials such as radios and newspapers and were confined to their cells 24 hours a day. These cells were devoid of chairs, tables and even beds. A mattress was the 
only item the prisoners had in these dark, wet, cold confines. The only faces they saw were those of the prison guards (or 'screws' as republicans call them) who often abused these inmates in an attempt to weaken their resolve. The only solace for these prisoners was the one monthly visit by relatives (Toolis 2000: 137; McKeown 2001: 53).

Six months later, prison officials banned the wearing of blankets outside the walls of the prison cell. This meant that taking the permitted weekly shower and going to the toilet became an exercise in sexual harassment by the prison guards who made unnerving and jeering comments about the prisoners' genitals. The blanket protest carried out by republican men in the H-Blocks quickly escalated into a dirty one when prison authorities withdrew what little privileges the men had left in an attempt to punish them for their participation in the protest. In defiance of their mistreatment, prisoners began to smear their own excrement and food on the walls of their cells. Prisoners refused to leave their cells at all, giving up access to showers and toilets. The prisoners wore their prison clothes only to accept visitors; the remainder of the time they had only a towel covering them. This created a problem when they showered, as this was the only towel in their possession. After their request for a second towel was rejected, the prisoners refused to wash, 'on the grounds that they should not be forced into nakedness' (Coogan 1995: 224). The guards taunted prisoners with food and would only partially empty the prisoners' chamber pots, or worse, spill their contents out onto the floor of the cell. In response, the prisoners threw their faeces out the cell windows only to have the guards throw it back at them. The prisoners, in turn, smeared their faecal matter all over their cells. ${ }^{12}$

In February 1977, 30 female republican prisoners at Armagh Jail joined their male comrades in support of this fight for political status. However, as the female republican prisoners in Armagh were allowed to wear their own clothes, their dirty strike did not originate in defiance of forced nakedness. The strike in Armagh, which commenced on 7 February 1980, several months after the strike in the H-Blocks began, arose out of a series of events that unfolded on that day.

Events began with close to thirty male officers entering the wing that housed the republican women. They proceeded to violently remove the women in order to search their cells. Many women were pulled out of the cells by the hair on their heads and were beaten, kicked and punched by these male officers in riot gear. When they were allowed to return to their cells, the women found them to be entirely destroyed, clothes strewn all around the tiny room and many of their belongings damaged (McCafferty 1981: 26). Female wardens had demolished their cells on previous occasions; the few possessions they were allowed - personal pictures and treats from home - were often destroyed. Although it had become home in a technical sense for these women, the cell bore no resemblance to the conditions a home usually provides. There was no sense of safety, privacy or retreat, the most common ingredients of a personal space or home. Instead, their cells and all the enclosed 
contents, right down to the bodies that occupied the space, were public, owned by the British government.

The searching of the cells on this day in 1980, however, unleashed a series of events that would soon become legend. When these women were returned to their cells, they were locked up for over twenty-four hours with no food or access to the toilet or washing facilities. Though fed after the first day of this turmoil, the women were continually denied access to the toilets. Their chamber pots overflowed with their waste. In essence, these republican women were forced into the same position as their male comrades at the H-Blocks - that of a Dirty Protest. It was from this point on that the women, in opposition to their treatment, refused to use the toilet and sink facilities when the 'privilege' was returned to them days later. These women were no longer willing to have their own bodies used against them and entered into the no wash strike in protest.

Under the circumstances, the only weapons the Armagh women had at their disposal were their bodies, weapons they cleverly and subversively employed. Like their male counterparts, female republican prisoners smeared their own excrement on the walls of their cells as a means of resistance. The women, however, had one more resource at their disposal - menstrual blood. In a society where women's reproductive functions are governed by strict codes of secrecy, the use of menstrual blood in a public protest was, in a word, 'shocking' to both the prison staff and to society in general. Decorating the cells with menstrual blood was the ultimate act of disruption and empowerment, of women taking control of their bodies to challenge the prison system. As Koutroulis (2001: 204) remarks about menstruation:

When this fluid [menstrual blood], as bold in its emergence as it is in its colour, spilt, it marked the distinctiveness of women, accentuating their difference, placing them in the category of 'other'. Any thought that the difference between men and women was subtle, became an illusion, shattered with the sight of menstrual fluid.

Visible menstrual blood meant a blatant disregard of menstrual 'etiquette' and posed a direct challenge to the societal norms that instituted this 'etiquette' in the first place. When republican women made visible their menstrual blood, the female republican body was transformed into a site of resistance, rather than 'an object of discipline and normalisation' (Davis 1995: 33).

As a consequence of the disciplinary practices applied to menstruating women, when the women of Armagh entered into the Dirty Protest, they were seen as more disgusting and shocking than their male counterparts. As Irish author Tim Pat Coogan stated after visiting both the H-Blocks and Armagh:

The 'Dirty Protest' is bad enough to contemplate when men are on it, but it becomes even worse when it is embarked on by women ... I found the smell 
in the girls' cells far worse than at Long Kesh, and several times found myself having to control feelings of nausea.

(Coogan 1980: 114)

The menstrual blood compounded the situation, as these women made public something that, in the minds of most people at the time, should have remained unseen. As Aretxaga points out (1997: 137), this thinking led the thirty women in Armagh to be deemed more revolting than the 400 dirty men of the H-Blocks.

Menstrual blood, in many ways seen as the ultimate form of dirt, was particularly useful in warding off unwanted trespassers. Wardens entered the cell only when they absolutely had to and when they did they wore masks, gloves, rubber boots and special 'insulating suits' that protected them from the living conditions of the prisoners (Aretxaga 1997: 136). These conditions in turn shielded the women from the prison officials. The following female prisoner's account of mealtime in Armagh illustrates the extent to which this was true:

I can see by her [female prisoner officer's] face that the stench in the cell must be pretty bad because even through the mask her face is in a grimace ... The screw has poured tea into the cups. I lift them immediately. She won't touch the mugs even though she has gloves on; they don't like to touch anything belonging to us ... I turn around and head back to the cell. As I do the three screws behind me start to laugh. The three up at my door just watch ... It used to annoy me the sniggering but not any more... They can laugh. But the false laughter fades when they open our doors, and the smell on the wing isn't so pleasant either. I'm used to it ... But I doubt if they'll ever get used to it.

(Coogan 1980: 121)

Under the circumstances, the wardens did not want to touch anything in the cells, including the prisoners. 'They felt defiled coming in contact with the prisoners', and therefore, as a member of one of the female Dirty Protestors explains, 'they didn't like to touch you during the Dirty Protest... so that became our little weapon' (Aretxaga 1997: 136). Hence, the defiling of the cells had created a home environment, a personal space that was often free from unwanted visitors and that allowed the bodies of the female prisoners to remain relatively untouched.

The trade-off for this semi-privacy, of course, was living in these appalling conditions. The women were locked in for twenty-three hours of every day, with the other time spent in the exercise yard or eating their paltry meals. Otherwise, they never saw the light of day; the windows and spy-holes of their cells had been boarded up to prevent the women from emptying their chamber pots through them. All forms of entertainment like television, radios, books and magazines were denied to them. Such conditions were harsh enough to endure without adding the fact that the women had not 
cleaned their bodies, including their hair and teeth, since the start of the protest. For three months at a time, the women were forced to wear the same clothes, including the same pair of underwear. To make matters worse, there were no sheets on the beds and they had only one blanket that was as dirty as their bodies (McCafferty 1981: 10). The only comfort these women had were sanitary towels that they used even when not menstruating, to line their underwear to help prevent them from contracting infections. The prison authorities, however, responded by allotting only two packages of these towels a month to each prisoner, a meagre amount that was not always sufficient for menstruating women. As one woman noted:

Once a month on a fixed day, whether we were menstruating or not just then, [the nurse] gives out either sanitary towels or tampax (you can't have both). The quantity is the same for each prisoner, no matter how heavy or light her period.

(D’Arcy 1981: 58)

The prison authorities treated sanitary napkins as privileges and therefore limited their allotment as a means of punishing the women on the Dirty Protest. As Fairweather, McDonough and McFaydean note: 'The fact that they had to sit in their own menstrual blood amid excreta and urine did not concern the prison authorities' (1984: 222). Their sole objective was to weaken these women and force them off the protest. As one woman noted, "criminalisation and sanitary towels go together. Criminal means clean. Political means dirty, they try to tell us'. ${ }^{13}$ If these women had chosen to submit to the prison system - to accept whole-heartedly its rules, regulations and accompanying abuse - then, like the women serving time for robbery, assault or other non-republican crimes, republican women would have had access to all the sanitary products they needed. Instead, these women were subjecting themselves to sterility and even death by participating in the Dirty Protest (McCafferty 1981: 10). This was a prominent worry for the women of Armagh, as Margaretta D'Arcy notes:

I was most scared about possible vaginal infections, which quite a few suffered from. We never changed our knickers or jeans, but one had to have some protection there. Most of the women wore sanitary towels but there were no sanitary belts, so much of the time in the exercise was spent in furtively hitching the towels into place out of view of the TV monitors. The problem of not washing during menstruation was solved by changing the tampax much more frequently that one would outside ... In the beginning you could get as many sanitary towels and tampax as you wanted. But then surgery came round and informed us that we were going to get them only on the first day of the month, and you had to choose between tampax or towels.

(D’Arcy 1981: 80) 
The female prisoners were quite aware of the gendered expectations around cleanliness. They in fact had the desire to have clean, attractive hair, to carry a perfume scent as they entered a room, to don make-up - in essence, to be feminine. In the words of D'Arcy, 'all sexuality had disappeared' (1981: 103). What D'Arcy overlooks is that sexuality, in fact, had not disappeared; the use of menstrual blood demarcated the Dirty Protest along gender lines in ways that mere faeces and urine could not. In fact, societal taboos that govern menstruation ensured that the use of menstrual blood by female republican prisoners was far more subversive than anything faeces or urine could offer. Therefore, when the female prisoners reclaimed their menstrual blood they were, in effect, re-gaining control over their own bodies.

\section{FEMINIST RESISTANCE BEYOND ARMAGH}

When republican women used menstrual blood to decorate the walls of Armagh jail, the effects were felt well beyond the gates of the prison. The women's protest sparked a debate within the women's movement in the North of Ireland that led to an irrevocable split among the feminist community. The women of Armagh and republican women active in the community saw the conditions of female political prisoners in Armagh as a clear feminist issue and called for the support of mainstream feminists in the North. The refusal of mainstream feminists to adopt Armagh as an issue within the movement forced republican women to fiercely organize within their own community, which gave rise to republican feminism. ${ }^{14}$

Female republican prisoners in Armagh were acutely aware of the gendered nature of their suffering and called for the support of women's groups in the North to help raise awareness of their plight. Despite the clearly gendered nature of the treatment of republican prisoners, mainstream women's groups in the North repeatedly refused to address Armagh for fears of being associated with the republican movement and 'terrorism' more generally. ${ }^{15}$ Women Against Imperialism, a group that formed out of existing women's groups as a result of their refusal to address Armagh, led the charge for republican women, releasing a report on the conditions in Armagh (Women Against Imperialism 1980). ${ }^{16}$ One page contained photographs of women struggling with the RUC on International Women's Day in 1979 , with a caption that read 'Make Armagh an Issue in the Women's Movement'. This statement called on feminists active in the campaign to end violence against women to recognize the hypocrisy in their turning a blind eye to the violence women experienced in prison. Noted Irish feminist and journalist Nell McCafferty ignited a ferocious and ultimately divisive debate when her article on Armagh was published in the Irish Times on 22 August 1980. McCafferty wrote: 
Since the suffering of women anywhere, whether self-inflicted or not, cannot be ignored by feminists, then we have a clear responsibility to respond [to the conditions in Armagh.] ... I believe that the ... women there have been denied one of the fundamental rights of women, the right to bodily integrity ...

(McCafferty 1980)

In response, a statement issued in October of 1980 by the Northern Ireland Women's Rights Movement, the leading women's group in the North at the time, reasoned:

The fact that a group of women prisoners is demanding political status does not make it any more a feminist issue, any more than the fact that Cumann na mBan [the women's auxiliary of the IRA] exists makes a united Ireland a feminist aim.

(Loughran 1985: 5)

This statement signaled a defining moment for the women's movement in the North. From this point on, two distinct feminist camps emerged in the North, as the tensions between republican and 'mainstream' feminists divided the movement (Loughran 1985; Aretxaga 1997; 0’Keefe 2003b). Republican feminism, on account of this estrangement, has blossomed into a distinctly separate movement of its own.

The formation of a Sinn Féin Women's Department in 1980 is perhaps the earliest and, no doubt, most significant success of republican feminists. Its most distinguished contribution is a women's policy document, the first of its kind for any of the political parties in the North of Ireland. This policy document, unanimously supported at the 1980 Ard Fheis (national conference), appeals for increased access to divorce, public childcare, childcare to be shared by both parents, free and accessible contraception (and the reprimand of those doctors who refuse to dispense contraceptives), non-directive pregnancy counseling and sex education (Cannavan 1988; Sinn Féin Women's Department 1994). The Women's Department has also brought to light women's involvement in the armed struggle, raising awareness of the roles and duties women have played in the various elements of the republican movement. The Department has been involved in campaigns against stripsearching and prisoners' welfare and has produced a number of publications to highlight the concerns of women within the movement and of Northern Irish women in general. Many of these publications address issues like the right to choose, contraception, childcare and similar issues that mirror the concerns of the broader women's movement. ${ }^{17}$

Women's centres in republican areas of the North are another success of the republican feminist movement. The first, Falls Women's Centre, was opened in 1983 in Catholic West Belfast. This women-only centre has counseled women on violence and sexual abuse and has worked with prisoners and their families. It provides crèche facilities for women who choose to work outside the home and organises education and training for women 
who want to take courses at a college or university level. ${ }^{18}$ The Centre also embarked on campaigns to publicise the issue of violence and abuse against women. The Falls Women's Centre played a pivotal role in the formation of the West Belfast Women's Network, an umbrella group established in 1996 to bring together groups to lobby for policy change at various levels of government (Falls Women's Centre 2001: 13). The Centre has been used widely by many women in the community and remains a constant for many women who feel uncomfortable venturing outside their own community for support.

Republican feminists continue to independently agitate for women's rights in the North on issues like gender violence (whether it be domestic or statesponsored), abortion, education, and equality in terms of class, sexual orientation and ethnicity (0'Keefe 2003a, b). They have left a distinct imprint on the political landscape of the North that the Dirty Protest in Armagh first mapped. It is important to note, however, that the role of menstrual blood is rarely discussed in the recollections of the Dirty Protest - it is obscured in the history of the Troubles, not unlike women's contribution to the republican armed struggle more generally. Nonetheless, those who served time in prison and particularly those who participated in the Dirty Protest, women and men alike, are revered within the republican community. ${ }^{19}$ Conversely, while menstruation does not directly occupy a significant space in the narratives about republican counter-hegemonic resistance, its implications are anything but negligible. The use of menstrual blood as a weapon of resistance to challenge the state by republican women blurred the public/private divide and transgressed gender norms in the most scrupulous of ways. The women on the Dirty Protest destabilised 'the disciplinary power that inscribes femininity on the female body' (Bartky 1995: 249), thereby transgressing powerful social norms that relegated women to the home and silenced 'women's issues' more generally. Their actions represented a challenged to the hegemonic project of the British state - something which continues through the struggle by republican women to gain further rights and freedoms whether it be in the area of reproductive rights or education, to name but a couple of examples.

This use of menstrual blood as a political instrument by the women in Armagh jail is important beyond the context of republican struggle against the British state. This act of defiance has broader implications for all women concerned with counter-hegemonic resistance. The role of women in the Dirty Protest demonstrates that it is possible for women to empower themselves by taking that which makes them vulnerable to their oppressors (in this case their ability to menstruate) and to reclaim it as a weapon of resistance. It reminds us that power is ultimately contestable. Finally, this paper should evoke questions about other examples of how menstruation is politicized and employed in both coercive and subversive ways. On a more general note, while there is a significant amount of research dedicated to understanding how women's bodies are targeted and exploited, our knowledge of how women reclaim their bodies to use against their oppressors is less developed. Further knowledge on the ways in which 
women choose to resist could, in turn, allow both feminist academics and activists alike to better strategize against hegemonic projects.

\author{
Theresa 0'Keefe \\ School of Social Justice \\ University College Dublin \\ Belfield, Dublin 4 \\ Ireland \\ Email: theresa.okeefe@ucd.ie
}

\title{
Notes
}

1 The idea for this article surfaced out of the interviews I conducted with Irish republican women in Ireland, North and South. The references to the women interviewed in this article are anonymous to protect the identity of those who revealed sensitive information on their involvement in Irish republican politics. I would like to thank Jennifer Suchland, Meghana Nayak, Andrea Schneider and Jonathan Greene for their comments on this paper.

2 I use the terms 'six counties' and 'North of Ireland' to refer to that part of the island of Ireland which is under British authority. I use these references instead of 'Northern Ireland' as that is how the republican women I interviewed refer to this geo-political space. Furthermore, the term 'republican' refers to those members of the nationalist community who support the armed struggle against the British occupation of the six counties.

3 It is important to point out that men also experienced sexualized violence at the hands of prison and law enforcement authorities and this is a topic that requires further study (McKeown 1999, 2001).

4 Armagh jail was a prison that housed female prisoners in the North of Ireland. In addition to the Dirty Protest, Armagh was also the site of a hunger strike by three female republican prisoners in 1980.

5 It is interesting to note that the label of dirty is often applied to the Irish as a whole (see Appel 1971; Darby 1983).

6 It has been noted that menstruation was clearly used as an excuse in Nazi concentration camps to punish and kill women (Laws 1990: 65).

7 One female republican activist and ex-prisoner told me that she was attracted to the republican movement because of conversations she had with women active in the movement concerning menstruation, contraception and choice. In her words, 'My mother didn't even talk to me about menstruation, let along having choices. That's why I became involved because I thought it was very progressive'. (Author interview with Anonymous \# 1, 16 October 2000, Belfast.)

8 It is important to point out that making connections between the British state and gendered violence in the North is a difficult task for a number of reasons. First, academics who work in Ireland (north and south) and research the conflict pride themselves on being 'objective' and aim not to be seen as taking sides. As a 
result, very little is written that is critical of the British state (Hillyard 1993; Campbell, McKeown and O'Hagan 1994 are among the notable exceptions). Even less has been written on this topic using a gender lens (Aretxaga 1997 and Harris and Healy 2001 are again notable exceptions). A second reason for the difficulties in writing on this topic is that very little has been written about women's involvement in the conflict. Work produced in this area tends to focus on women's cross-community/bridge-building/peace-making roles (McWilliams 1993; Sales 1997; Cockburn 1998). Accounts of women's experiences with gendered violence that is state-directed are therefore limited.

9 See also the report of the Stevens Inquiry (Stevens 2002), which highlights this relationship between security forces and loyalist paramilitaries.

10 In one case a woman lost her virginity through the interrogation she underwent and was awarded an out-of-court settlement. See 'Sexual Harassment: British Occupation' (n.d.: 12) and also Friel (1998), Murray (1998) and Harris and Healy (2001). In addition, see Morris (2003) for a discussion of the recent rape investigations against five members of the PSNI in Belfast.

11 Author interview with Anonymous \#2, 17 October 2000, Belfast.

12 The conditions in these maggot-infested cells became unimaginable to anyone but their inhabitants and prompted the beginning of a hunger strike, led by Brendan Hughes, in October 1980 (Coogan 1995: 227).

13 This statement is by Liz Lagrua, a member of Women Against Imperialism who voluntarily entered Armagh to join the Dirty Protest in support of the republican prisoners, (quoted in McCafferty 1981: 13).

14 The confines of this paper do not allow for an extensive discussion of the history of women's organizing in the North and an account of the remaining factors that gave rise to republican feminism. For further detail see 0'Keefe (2003b).

15 For further discussion of the tensions between the autonomous women's movement and republican women with regard to the prison struggles, see 0'Keefe (2003a and in press).

16 This report described the lack of medical attention provided to all prisoners in Armagh, as the gaol (jail) had only one doctor. The attention women did receive was often complacent and dismissive, with the doctor being more prone to prescribe treatment for the'woman problem' as opposed to any other conditions. The food situation was also studied; meals were anything but nutritious, were always served cold and half-cooked and were insufficient in portions. The report also mentions the harsh verbal abuse many prisoners faced during interrogations, abuse that entailed sexually harassing language like 'whore'.

17 Women in Struggle and A Woman's Voice are some of the various publications in which such examples can be found.

18 Falls Women's Centre 2001: 6 and author interview with Oonagh Marron, Director of the Falls Women's Centre, 23 October 2000, Belfast.

19 In fact it could be argued that the respect garnered by women who participated in the Dirty Protest opened up a space for them within the higher ranks of the republican movement. Mairéad Farrell for instance, was General Headquarters staff, the 
top decision-making body of the IRA. Similarly, many female ex-prisoners are active within Sinn Féin.

\section{References}

Amnesty International. 1978. Report of an Amnesty International Mission to Northern Ireland (28 Nov.-06 Dec. 1977). London: Amnesty International.

Appel, J. 1971. 'From Shanties to Lace Curtains: The Irish Image in Puck, 1876-1910', Comparative Studies in Society and History 13 (4): 365-75.

Aretxaga, B. 1997. Shattering Silence: Women, Nationalism and Political Subjectivity in Northern Ireland. Princeton: Princeton University.

Aretxaga, B. 2001. 'The Sexual Games of the Body Politic: Fantasy and State Violence in Northern Ireland', Culture, Medicine and Psychiatry 25 (1): 1-27.

Bartky, S. L. 1995. 'Foucault, Femininity and the Modernization of Patriarchal Power', in Mehuron, K. and Percesepe, G. (eds) Free Spirits: Feminist Philosophers on Culture, pp. 240 -56. Englewood Cliffs, NJ: Prentice-Hall.

Campbell, B., McKeown, L. and O'Hagan, F. (eds). 1994. Nor Meekly Serve My Time The H Block Struggle 1976-1981. Belfast: Beyond the Pale Publications.

Cannavan, J. 1988. ‘Women's Struggle Liberates Ireland/Ireland's Struggle Liberates Women: Feminism and Irish Republicanism.' Irish Women's History Group, 6. Pamphlet at Linen Hall Library's Northern Ireland Political Collection. Also available online at www.etext.org/Politics/INAC/irish.women (accessed 13 July 2006).

Cockburn, C. 1998. The Space Between Us: Negotiating Gender and National Identities in Conflict. London: Zed Books.

Cockburn, C. 2001. 'The Gendered Dynamics of Conflict', in Mosher, C. and Clark, F. (eds) Victims, Perpetrators or Actors? Gender, Armed Conflict and Political Violence, pp. 13-29. London and New York: Zed Books.

Coogan, T. P. 1980. On The Blanket: The H-Block Story. Dublin: Ward River.

Coogan, T. P. 1995. The Troubles. London: Hutchinson.

Copelon, R. 1998. 'Surfacing Gender: Reconceptualizing Crimes Against Women in Times of War', in Lorentzen, L. and Turpin, J. (eds) The Women and War Reader, pp. 63 -79. New York: New York University.

D’Arcy, M. 1981. Tell Them Everything. London: Pluto Press.

Darby, J. 1983. Dressed to Kill: Cartoonists and the Northern Ireland Conflict. Belfast: Appletree.

Davis, K. 1995. Reshaping the Female Body. The Dilemma of Cosmetic Surgery. New York and London: Routledge.

De Troyer, K., Herbert, J. and Johnson, J. 2003. Wholly Woman Holy Blood: A Feminist Critique of Purity and Impurity. Harrisburg, PA: Trinity Press International.

Douglas, M. 1966. Purity and Danger: An Analysis of Conceptions of Pollution and Taboo. London: Routledge and K. Paul.

Fairweather, E., McDonough, R. and McFadyean, M. 1984. Only the Rivers Run Free: Northern Ireland, the Women's War. London: Pluto Press. 
Falls Women's Centre. 2001. Supporting Women in the Year 2001 - Development Plan, Belfast.

Faul, Fr. D., and Murray, Fr. R. 1972. British Army and Special Branch Brutalities, 1971 - 1972. Dungannon: Dennis Faul.

Friel, L. 1998. 'The Shameful Record of British Torture', An Phoblacht/Republican News, December: 17.

Grosz, E. 1995. Space, Time and Perversion: Essays on the Politics of Bodies. London: Routledge.

Harris, H., and Healy, E. (eds). 2001. 'Strong About it All . .'? Rural and Urban Women's Experiences of the Security Forces in Northern Ireland. Derry City: Northwest Women's/Human Rights Project.

Hillyard, P. 1993. Suspect Community. London: Pluto Press.

Houppert, K. 1999. The Curse. Confronting the Last Unmentionable Taboo: Menstruation. New York: Farrar, Straus and Giroux.

Inglis, T. 1987. Moral Monopoly: The Catholic Church in Modern Irish Society. Dublin: Gill and Macmillan.

Koutroulis, G. 2001. 'Soiled Identity: Memory-Work Narratives of Menstruation', Health 5 (2): 197-205.

Laws, S. 1990. Issues of Blood: The Politics of Menstruation. Basingstoke: Macmillan.

Leddy, T. 1995. 'Everyday Surface Aesthetic Qualities: "Neat”, "Messy", “Clean", "Dirty", The Journal of Aesthetics and Art Criticism 53 (3): 259-68.

Loughran, C. 1985. 'Strip Searches Continue', Women's News, 11 (Summer): 5.

Maghaberry Republican Prisoner's Statement. 1987. Women's News, Issue 25 (April): 17.

McArdle, M. and Carrol, A. 1992. 'Arrest, Detention and Interrogation', Women in Struggle 3 (October): 6.

McCafferty, N. 1980. Untitled weekly column. Irish Times, 22 August.

McCafferty, N. 1981. The Armagh Women. Dublin: Co-op Books.

McGarry, J. and B. O'Leary. 1995. Explaining Northern Ireland. Oxford: Blackwell.

McKeown, L. 1999. 'Gender and the Social Construction of an Irish Republican Prisoner Community.', Paper presented at the Annual Convention of the International Studies Association, 17-21 February, Washington, DC.

McKeown, L. 2001. Out of Time: Irish Republican Prisoners. Long Kesh 1972-2000. Belfast: Beyond the Pale.

McWilliams, M. 1993. 'Women in Northern Ireland: An Overview', in Hughes, E. (ed.) Culture and Politics in Northern Ireland: 1960-1990, pp. 81-100. Milton Keynes: Oxford University Press.

Morgan, K. P. 1991. 'Women and the Knife: Cosmetic Surgery and the Colonization of Women's Bodies', Hypatia 6 (3): 25-53.

Morris, A. 2003. 'PSNI Rape Shock.' Andersonstown News, April 14

Murphy, B. 1989. 'A Curse', in DeSalvo, L., D'Arcy, K. W., and Hogan, K. (eds) Territories of the Voice: Contemporary Stories by Irish Women Writers, pp. 226-7. Boston: Beacon Press.

Murray, R. 1998. State Violence in Northern Ireland 1967-97. Cork: Mercier Press.

Nikolic-Risanovic, V. 1998. 'War, Nationalism, and Mothers in the Former Yugoslavia', in Lorentzen, L. and Turpin, J. (eds) The Women and War Reader, pp. 195-210. New York: New York University Press. 
O’Brien, M. 1981. The Politics of Reproduction. London: Routledge.

0'Keefe, T. 2003a. 'The Mini-Skirt Brigade: Feminist Identity Construction in the Irish Republican Movement'. PhD Dissertation, Department of Political Studies, Queen's University at Kingston, Canada.

0'Keefe, T. 2003b. 'Trading Aprons for Arms: Republican Feminist Resistance in the North of Ireland', Resources for Feminist Research 30 (3/4): 34-57.

0'Keefe, T. In press. 'Reformation versus Revolution: A Comparison of Feminist Agendas in the North of Ireland', Women's Studies International Forum.

Pickering, S. 2001. 'Undermining the Sanitized Account: Violence and Emotionality in the Field of Northern Ireland', British Journal of Criminology 41 (3): 485-501.

Sales, R. 1997. Women Divided: Gender, Religion and Politics in Northern Ireland. London: Routledge.

'Sexual Harrassment: British Occupation'. n.d. [1980s]. In Women in Ireland, mimeographic pamphlet, published by Women's Group, New Zealand H-Block/Armagh Committee. Available at Linen Library Northern Ireland Political Collection.

Sinn Féin Women's Department. 1994. Women in Struggle/Mna I Streachailt, Volume 1 (Autumn): 9

Stevens, J. 2002. Stevens Inquiry: Overview and Recommendations. April 17.

'Strip-Searching ... Violence Against Women. Prisoner's Statement'. 1986. Women's News, Issue 21 (November): 6.

'Testimony of Mairéad Farrell'. 1987. Women's News, Issue 25 (April): 13.

Thapar-Björkert, S. and Ryan, L. 2002. 'Mother India/Mother Ireland: Comparative Gendered Dialogues of Colonialism and Nationalism in the Early 20th Century', Women's Studies International Forum 25 (3): $301-13$.

Toolis, K. 2000. Rebel Hearts: Journeys Within the IRA's Soul. London: Picador Press. Turshen, M. 2001. 'The Political Economy of Rape: An Analysis of Systematic Rape and Sexual Abuse of Women during Armed Conflict in Africa', in Moser, C. and Clark, F. C. (eds) Victims, Perpetrators or Actors: Gender, Armed Conflict and Political Violence, pp. 55-68. London: Zed Books.

Weitz, R. 2001.'Women and their Hair: Seeking Power Through Resistance and Accommodation', Gender and Society 15 (5): $667-86$.

Women Against Imperialism. 1980. Women Protest for Political Status in Armagh Gaol. Belfast.

Women's News. 1984. Issue 7 (December): 4.

Women's News. 1991. Issue 55 (September/October): 5. 